\title{
Natural cryptomelane and its potential application in the adsorption of heavy metal cadmium
}

\author{
Anhuai $\mathrm{LU}^{*}$, Xiang GAO ${ }^{* *}$, Changqiu WANG ${ }^{*}$, Yongwen GAO ${ }^{* * *}$, Desheng ZhenG ${ }^{*}$, \\ Tianhu CHEN $^{* * * *}$, Dongjun ZHAO* and Shan QIN ${ }^{*}$ \\ *Department of Geology, Peking University, Beijing 100871, P. R. China \\ ${ }^{* *}$ Laboratory Center of Geology, China University of Geosciences, Beijing 100083, P. R. China \\ ${ }^{* * * *}$ Makah Fisheries Management, P.O. Box 115, Neah Bay, WA 98357, USA \\ ${ }^{* * *}$ School of Natural Resources and Environmental Engineering, Hefei University of Technology, \\ Hefei 230009, P. R. China
}

\begin{abstract}
The Xiangtan manganese deposit (XTM) was formerly considered a supergene oxide manganese deposit in South China. Here, we report upon a new identification of naturally outcropping cryptomelane from the XTM, rather than psilomelane and pyrolusite, as it was previously considered. Most crystals in aggregates of XTM cryptomelane are acicular, with a diameter from $20 \mathrm{~nm}$ to $120 \mathrm{~nm}$. There are large pseudotetragonal tunnels in the cryptomelane formed by $\left[\mathrm{MnO}_{6}\right]$ octahedral double chains with an aperture of $0.462 \times 0.466 \mathrm{~nm}^{2}$. The importance of our find relates not only to manganese resource prospecting in South China, but also to the application of the octahedral molecular sieve of cryptomelane. On the basis of the study of some mineralogical characteristics, experiments on heavy metal cadmium adsorption have been done. The overall adsorption capacity of cryptomelane for $\mathrm{Cd}^{2+}$ with different electrolytes showed an increase with a $\mathrm{pH}$ rise from 3 to 11.5. This work also showed that in addition to an ion exchange with $\mathrm{H}^{+}$, the adsorption of $\mathrm{Cd}^{2+}$ might involve exchange with $\mathrm{Mn}$ and $\mathrm{K}$ cations in the cryptomelane structure. Isotherms for $\mathrm{Cd}^{2+}$ adsorption in about neutral $\mathrm{pH}$ solutions can be satisfactorily represented by the Langmuir expression and the theoretic maximum disposal capacity thus determined is $5.54 \mathrm{mg} / \mathrm{g}$.
\end{abstract}

Keywords: Natural cryptomelane, Octahedral molecular sieve, Adsorption of Cd

\section{INTRODUCTION}

The Xiangtan manganese deposit (XTM) is rich in manganese ore of high quality, and is known to be the primary Chinese manganese deposit. Lu et al. (2003) reported a new location of naturally outcropping cryptomelane, and also made comparisons between this cryptomelane and the tetrahedral molecular sieve of zeolite. Cryptomelane has a variable valence state for manganese in its structure and XTM cryptomelane might therefore be a useful natural adsorbent mineral with an octahedral molecular structure. This recognition may have a profound influence in mineralogy and material science.

Firstly, it is clearly an important discovery of a rich manganese source because cryptomelane has not previously been reported to occur on a large scale before (Ramsdell, 1932; Richmond and Fleischer, 1942).

Secondly, the theoretic formula of natural cryptome-

doi:10.2465/jmps.060412

A. Lu, ahlu@pku.edu.cn Corresponding author lane is $\mathrm{K}_{\mathrm{x}} \mathrm{Mn}_{8-\mathrm{x}}^{4+} \mathrm{Mn}_{\mathrm{x}}^{3+} \mathrm{O}_{16}$, where $\mathrm{x}$ ranges from 0.2 to 1.0 (Mukherjee, 1959; Vicat et al., 1986). Since the 1980s, experimental research on synthetic cryptomelane has gained considerable international attention (Shen et al., 1993) and it is classified as an octahedral molecular sieve based on its $2 \times 2$ tunnel structure, which is composed of edge-sharing $\left[\mathrm{MnO}_{6}\right]$ octahedra with double chains. It has great potential use in ion exchange and battery applications, radioactive waste immobilization, and as a catalyst (Luo et al., 2000).

Naturally occurring manganese dioxide minerals are highly chemically active and powerful scavengers of heavy metals (Post, 1999). Their synthetic analogues have been studied during investigation of adsorptive properties (Morgan and Stumm, 1964; Posselt et al., 1968; Murray, 1975a, 1975b; Murray and Dillard, 1979; McKenzie, 1970, 1980). Research has investigated the adsorption of alkali, alkaline earth, and transition metal cations on synthetic cryptomelane (Tsuji and Komarneni, 1993a, 1993b; Feng et al., 1995). The ion exchange is selective for cat- 
ions with an effective ionic radius of $\sim 1.4 \AA$ and several divalent transition metal ions $(\mathrm{Pb}, \mathrm{Mn}, \mathrm{Co}, \mathrm{Cu}, \mathrm{Hg}, \mathrm{Cd}$, $\mathrm{Zn}$, and $\mathrm{Ni}$ ) are adsorbed within the tunnels of cryptomelane. These ion exchange properties have proved useful and the application of this material as an ionic sieve has been reported (Tsuji and Komarneni, 1993b; Elnaggar et al., 1993; Yin et al., 1994; DeGuzman et al., 1994).

Cadmium, a highly toxic heavy metal, is prone to accumulate in the environment. It generally resides in soils and aquifers and is harmful to plants and animals. This poison can enter the human body via the food chain and affect normal kidney and liver function, thereby resulting in disease. Several studies into disposal of cadmium contamination have shown its adsorption on synthetic cryptomelane (Tsuji and Komarneni, 1993b; Randall et al., 1998). In this paper, we not only present some new mineralogical data on XTM cryptomelane, including cell parameters, size of the crystal aggregate, TEM and AFM images, etc., but we also report on experiments into cadmium adsorption on XTM cryptomelane and discuss its application in the removal of this element from wastewater.

\section{MATERIALS AND METHODS}

Natural XTM cryptomelane was examined by X-ray powder diffraction (XRD), XRD was carried out with a Rigaku D-MAX 2400, Japan, with $\mathrm{Cu} K \alpha$ radiation using $50 \mathrm{Kv}$ with $120 \mathrm{~mA}$ at room temperature (Lu et al., 2003). The sample was crushed and was gently ground in an agate mortar to a grain size of about 320 mesh. It was then pressed into a plane by glass slide on the sample platform for testing.

The morphological features and the grain size of crystal aggregate for XTM cryptomelane were investigated using atomic force microscopy (AFM) (Benyuan, CSPM-2001). Cryptomelane was polished, mounted on a sample platform, and then observed at room temperature.

A transmission electron microscope experiment (TEM) using a JEOL JEM-2010 was performed with a lattice resolution of $0.14 \mathrm{~nm}, 0.194 \mathrm{~nm}$ point-to-point to obtain atomic-scale images. Selected-area electronic diffraction (SAED), and X-ray energy disperse spectrometry (EDS) results were also obtained. During the TEM analysis, two samples were examined. A small sample was gently ground in a mortar and dispersed in analytical grade ethanol into dilute suspension. This was dripped onto a carbon-coated, fine mesh, copper grid.

The chemical composition analysis was performed using a $\mathrm{Si}(\mathrm{Li}) \mathrm{X}$-ray EDS Link system, ISIS instrument mounted with a detector behind a thin Be window. To determine the chemical composition, selected individual crystals were placed in the center hole of the copper grid and the sample holder slide was tilted $10^{\circ}$. A count time of $100 \mathrm{~s}$ was selected. The element abundances were calculated from the peak areas using a ZAF program and expressed as oxide weight percentages. Detection limits were equal to or less than $0.5 \%$.

The experiment to determine the $\mathrm{pH}$ value for the zero point of charge $\left(\mathrm{pH}_{\mathrm{zpc}}\right)$ was performed using a $\mathrm{ZC}-$ 2000 Zeta Potential Analyzer (Macrotech Nichion). A small sample at 200 mesh was gently ground in an agate mortar and dispersed into dilute suspension in analytical grade ethanol, in preparation for use.

XTM natural cryptomelane was prepared in a ball mill as powder and sieved to a grain size from 95 to 120 mesh to use for the adsorption experiments. Samples were washed by distilled water to clean the mineral surfaces, and heated at $80{ }^{\circ} \mathrm{C}$ for $10 \mathrm{~h}$. All reagents were prepared in the laboratory to analytical grade and distilled water was used to dilute their concentration. Model wastewater containing $\mathrm{Cd}^{2+}$ was prepared with $\mathrm{CdCl}_{2}$, and $\mathrm{HCl}$ and $\mathrm{NaOH}$ were used to adjust the $\mathrm{pH}$ with a $\mathrm{pHs}-2 \mathrm{C}$ digital acidometer. The reaction vessels were $100 \mathrm{ml}$ tricorn conical flasks. An atomic fluorescence photometer (AFS1201) was used to measure the concentration of the initial solution and supernatancy of $\mathrm{CdCl}_{2}$. The adsorption experiments progressed in a HZS-H constant-temperature oscillator with a constant shaking speed of $190 \mathrm{r} /$ minute. The suspensions were separated with an 80-2B desk centrifuge.

Experiments to determine the equilibrium time, leaching, and retention, and isotherms for the adsorption of $\mathrm{Cd}^{2+}$ were carried out at about $25{ }^{\circ} \mathrm{C}$ under a neutral

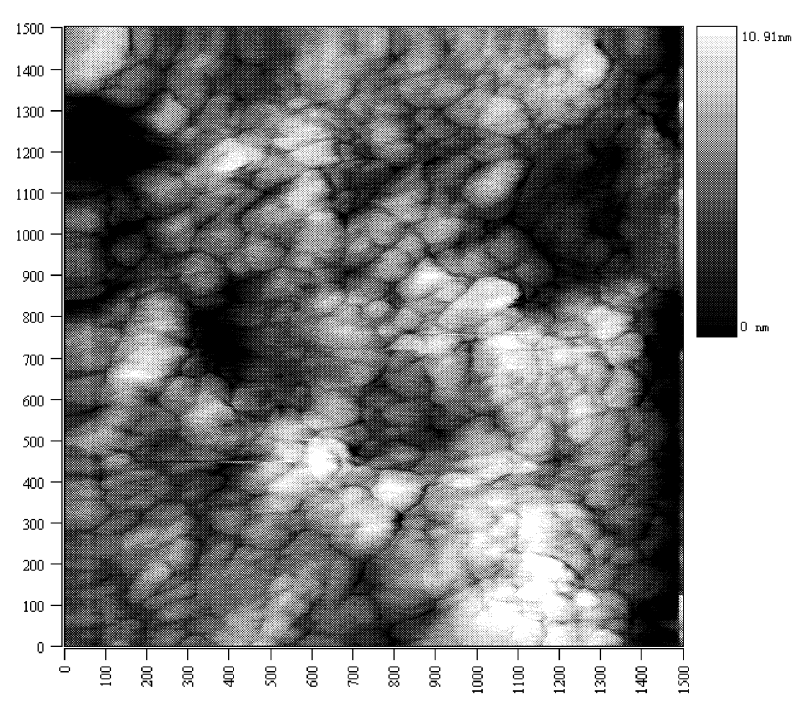

Figure 1. Features of nanograde particles on the surface of XTM cryptomelane seen by atomic force microscope. 

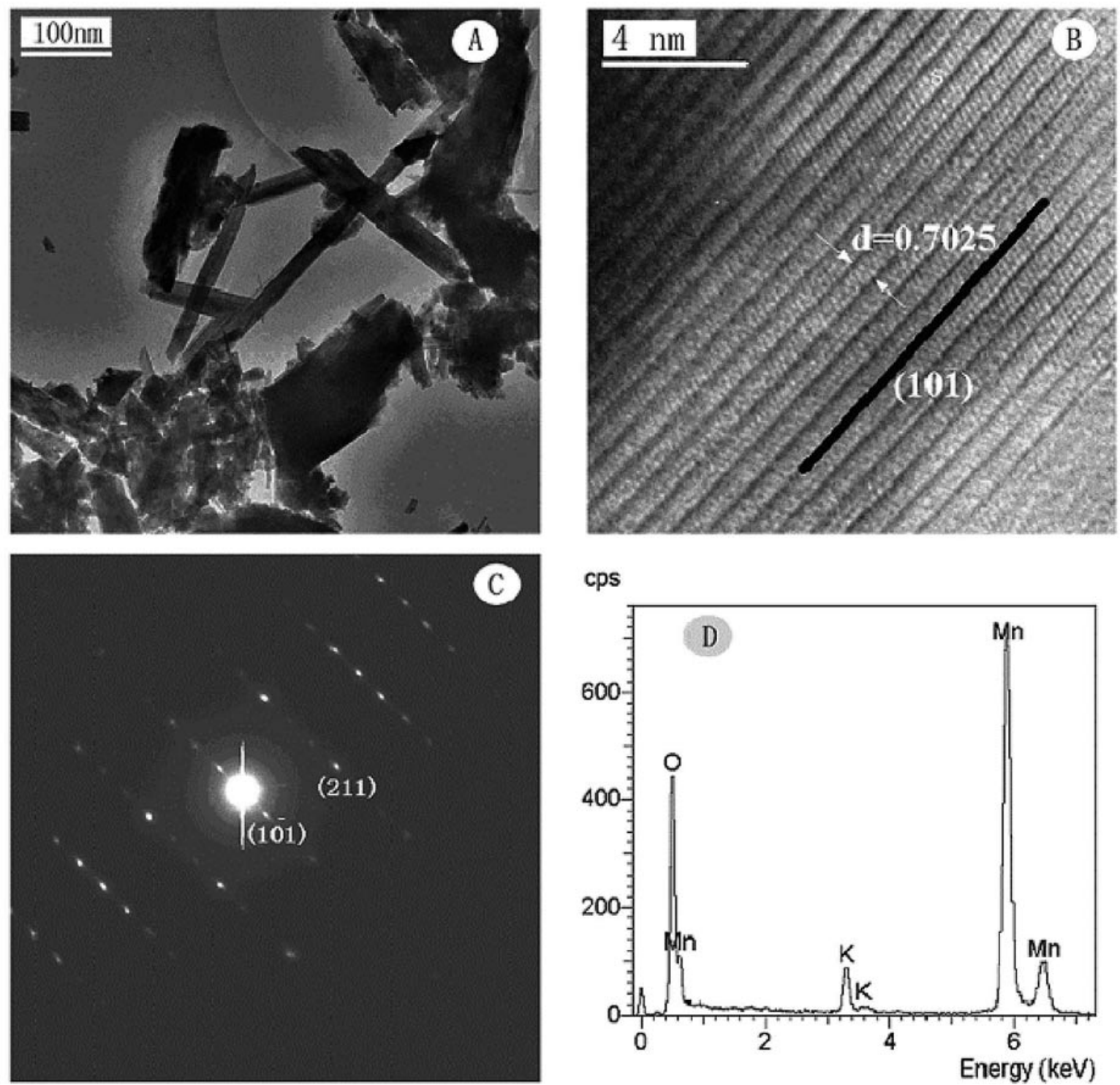

Figure 2. The crystal form, structure, and chemical composition of XTM cryptomelane seen by transmission electron microscope. (A) The acicular crystal habit of cryptomelane. Length 20-120 nm. (B) Stripe image of crystal lattice for cryptomelane. (C) SAED of the cryptomelane taken down the crystal structure a axis. (D) Chemical composition of cryptomelane indicated by EDS.

$\mathrm{pH}$, and at differing $\mathrm{pH}$ values using various electrolytes. Cryptomelane powder was weighed into $0.2 \mathrm{~g}$ quotients and placed into each flask. Then, $100 \mathrm{ml}$ of $5 \mathrm{mg} / \mathrm{L} \mathrm{CdCl}_{2}$ solutions was added. The suspensions were surged and the concentration of $\mathrm{Cd}^{2+}$ was measured at intervals. For varied $\mathrm{pH}, 0.05 \mathrm{~g}$ of powder was put into each flask, and $50 \mathrm{ml}$ of $2 \mathrm{mg} / \mathrm{L} \mathrm{CdCl} \mathrm{Cl}_{2}$ with electrolyte as $0.02 \mathrm{~mol} / \mathrm{L}$ $\mathrm{NaCl}, \mathrm{NaNO}_{3}, \mathrm{KCl}, \mathrm{K}_{2} \mathrm{SO}_{4}$, and $\mathrm{CaCl}_{2}$ were respectively added.

In the isotherm experiment for $\mathrm{Cd}^{2+}$ adsorption, $0.2 \mathrm{~g}$ of cryptomelane powder and $100 \mathrm{ml}$ of corresponding solution was added where the concentration of $\mathrm{Cd}^{2+}$ in $\mathrm{mg} / \mathrm{L}$ were $1,2,5,10,20,50$, and 100, respectively. The suspensions were surged for $72 \mathrm{~h}$ and separated by centrifuge. In the leaching and holding experiment, $2 \mathrm{~g}$ samples were put into $250 \mathrm{ml}$ flasks, and $200 \mathrm{ml}$ of $200 \mathrm{mg} / \mathrm{L}$ $\mathrm{CdCl}_{2}$ solution was added. After surging for $20 \mathrm{~h}$, the suspensions were filtered and measured for their $\mathrm{Cd}^{2+}$ concentration. A portion of the filtered residue was cleaned ultrasonically for $20 \mathrm{~min}$ and further slowly leached in distilled water. The cleaned and uncleaned filter residues were dried at $80^{\circ} \mathrm{C}$ for $6 \mathrm{~h}$, and the $\mathrm{Cd}^{2+}$ was measured by an IRIS Advantage-ICP (TJA, USA). 
Table 1. The chemical composition of XTM cryptomelane of individual crystals by TEM-EDS (wt \%)

\begin{tabular}{cccc}
\hline Number & $\mathrm{K}_{2} \mathrm{O}$ & $\mathrm{MnO}$ & \multicolumn{2}{c}{ Formula } \\
\hline $\mathrm{Mn}-\# 1-01$ & 6.89 & 93.11 & $\mathrm{~K}_{0.89} \mathrm{Mn}^{2+}{ }_{0.45} \mathrm{Mn}^{4+}{ }_{7.55} \mathrm{O}_{16}$ \\
$\mathrm{Mn}-\# 1-02$ & 5.85 & 94.15 & $\mathrm{~K}_{0.74} \mathrm{Mn}^{2+}{ }_{0.37} \mathrm{Mn}^{4+}{ }_{7.63} \mathrm{O}_{16}$ \\
$\mathrm{Mn}-\# 1-05$ & 4.99 & 95.01 & $\mathrm{~K}_{0.63} \mathrm{Mn}^{2+}{ }_{0.32} \mathrm{Mn}^{4+}{ }_{7.68} \mathrm{O}_{16}$ \\
$\mathrm{Mn}-\# 1-06$ & 4.54 & 95.46 & $\mathrm{~K}_{0.57} \mathrm{Mn}^{2+}{ }_{0.29} \mathrm{Mn}^{4+}{ }_{7.71} \mathrm{O}_{16}$ \\
$\mathrm{Mn}-\# 1-08$ & 5.44 & 94.56 & $\mathrm{~K}_{0.69} \mathrm{Mn}^{2+}{ }_{0.35} \mathrm{Mn}^{4+}{ }_{7.65} \mathrm{O}_{16}$ \\
$\mathrm{Mn}-\# 1-17$ & 5.08 & 94.92 & $\mathrm{~K}_{0.64} \mathrm{Mn}^{2+}{ }_{0.32} \mathrm{Mn}^{4+}{ }_{7.68} \mathrm{O}_{16}$ \\
$\mathrm{Mn}-\# 3-01$ & 5.66 & 94.34 & $\mathrm{~K}_{0.72} \mathrm{Mn}^{2+}{ }_{0.36} \mathrm{Mn}^{4+}{ }_{7.64} \mathrm{O}_{16}$ \\
$\mathrm{Mn}-\# 3-02$ & 5.23 & 94.77 & $\mathrm{~K}_{0.67} \mathrm{Mn}^{2+}{ }_{0.34} \mathrm{Mn}^{4+}{ }_{7.66} \mathrm{O}_{16}$ \\
$\mathrm{Mn}-\# 3-04$ & 5.23 & 94.77 & $\mathrm{~K}_{0.67} \mathrm{Mn}^{2+}{ }_{0.34} \mathrm{Mn}^{4+}{ }_{7.66} \mathrm{O}_{16}$ \\
$\mathrm{Mn}-\# 3-05$ & 5.55 & 94.45 & $\mathrm{~K}_{0.71} \mathrm{Mn}^{2+}{ }_{0.36} \mathrm{Mn}^{4+}{ }_{7.64} \mathrm{O}_{16}$ \\
$\mathrm{Mn}-\# 3-25$ & 4.42 & 95.58 & $\mathrm{~K}_{0.55} \mathrm{Mn}^{2+}{ }_{0.28} \mathrm{Mn}^{4+}{ }_{7.72} \mathrm{O}_{16}$ \\
$\mathrm{Mn}-\# 3-26$ & 5.63 & 94.37 & $\mathrm{~K}_{0.72} \mathrm{Mn}^{2+}{ }_{0.36} \mathrm{Mn}^{4+}{ }_{7.64} \mathrm{O}_{16}$ \\
\hline
\end{tabular}

\section{CHARACTERISTICS OF CRYPTOMELANE}

XTM supergene oxide manganese ore generally occurs as a cryptocrystalline aggregate with noticeable conchoidal, botryoidal, reniform, and stalactitic forms. The physical characteristics of the mineral are recognized as a dull black surface, steel-gray to bluish-gray color on a fresh fracture, a brownish-black streak, hardness of 6-7, and concentric banding in cross section. These identification features agree well with those of cryptomelane (Wang et al., 1982). Further examination by XRD and infrared spectroscopy showed that the majority of oxide manganese minerals were composed of monoclinic cryptomelane (Gao et al., 2001; Lu et al., 2003).

\section{Grain size}

Analysis by AFM showed that in the range of $1500 \mathrm{~nm} \times$ $1500 \mathrm{~nm}$, the crystal aggregates of cryptomelane were closely compacted with a low degree of idiomorphism and rounded hull (Fig. 1). Most crystals were acicular in form with a diameter from $20 \mathrm{~nm}$ to $120 \mathrm{~nm}$ based on TEM images (Fig. 2A), which seems in agreement with XRD peaks, that is, having the characteristics of high background, broadening, and asymmetry. The crystal lattice image and electronic diffraction pattern of the cryptomelane are also displayed. (Fig. 2B, C).

\section{Chemical composition}

It is known that the structure of cryptomelane consists of a framework containing large tunnels filled by $\mathrm{K}$ cations whose presence balances the residual negative charges in a structure resulting from some $\mathrm{Mn}^{2+}$ substituting for $\mathrm{Mn}^{4+}$.

The chemical composition of XTM cryptomelane is shown in Table 1 and Figure 2D following TEM-EDS analysis of individual crystals. Because of having an acicular form, it is easy to select a single mineral crystal for chemical composition analysis by EDS to avoid interference from other minerals. The total $\mathrm{MnO}$ content was between $93.11 \%$ and $95.58 \%$, and $\mathrm{K}_{2} \mathrm{O}$ ranged from $4.42 \%$ to $6.89 \%$.

\section{Crystal structure}

The XRD pattern represents the characteristics of high background, broadening, and asymmetric peaks. It can be successfully indexed as a monoclinic structure (Fig. 3). Based on 20 observed peaks, the cell parameters were refined with the PIRUM program (Acosta et al., 1991) and given as $a_{0}=0.9974 \pm 0.0007 \mathrm{~nm}, b_{0}=0.2863 \pm$ $0.0001 \mathrm{~nm}, c_{0}=0.9693 \pm 0.0007 \mathrm{~nm}$, and $\beta=91.47^{\circ} \pm$ $0.01^{\circ}$. From the crystal structure modeling, there is a large pseudotetragonal tunnel in natural cryptomelane, which is formed by $\left[\mathrm{MnO}_{6}\right]$ octahedral double chains with an aperture of $0.462 \times 0.466 \mathrm{~nm}^{2}$ (Fig. 4).

\section{ADSORPTION OF CADMIUM}

\section{Adsorption experiment}

The zeta potential of the natural cryptomelane granules in suspension was measured at different $\mathrm{pH}$ values (Fig. 5). The intersection of the curve and coordinate axis suggest that the $\mathrm{pH}$ value of zero point of charge $\left(\mathrm{pH}_{\mathrm{zpc}}\right)$ for the sample was about 6.3. This is higher than that of other manganese oxides, which have lower $\mathrm{pH}_{\mathrm{zpc}}$ values ranging from 2 to 4 (Healey et al., 1966; McKenzie, 1981).

The data on reaction time, disposal capacity, and disposal percentage are shown in Table 2 and Figure 6. The adsorption of $\mathrm{Cd}^{2+}$ on cryptomelane showed that the disposal percentage was $44.3 \%$ within $1 \mathrm{~h}$, reached $58.0 \%$ within $6 \mathrm{~h}$, and was near to $62 \%$ within $12 \mathrm{~h}$. As shown in Figure 6 , if the disposal capacity at $72 \mathrm{~h}$ is regarded as the maximum, it is certain that $97 \%$ of the adsorption takes place in a $48 \mathrm{~h}$ reaction. It is therefore proposed that the time required for adsorption equilibrium is more than two days.

Morgan and Stumm (1964) and Posselt et al. (1968) suggest that $1 \mathrm{~h}$ is required to attain equilibrium during the adsorption of $\mathrm{Mn}^{2+}$ and other cations by $\delta-\mathrm{MnO}_{2}$. Murray et al. (1968) report an equilibrium time of several hours for the adsorption of $\mathrm{Co}^{2+}$ or $\mathrm{Cu}^{2+}$ and other metals by manganous manganate. Loganathan and Burau (1973) 


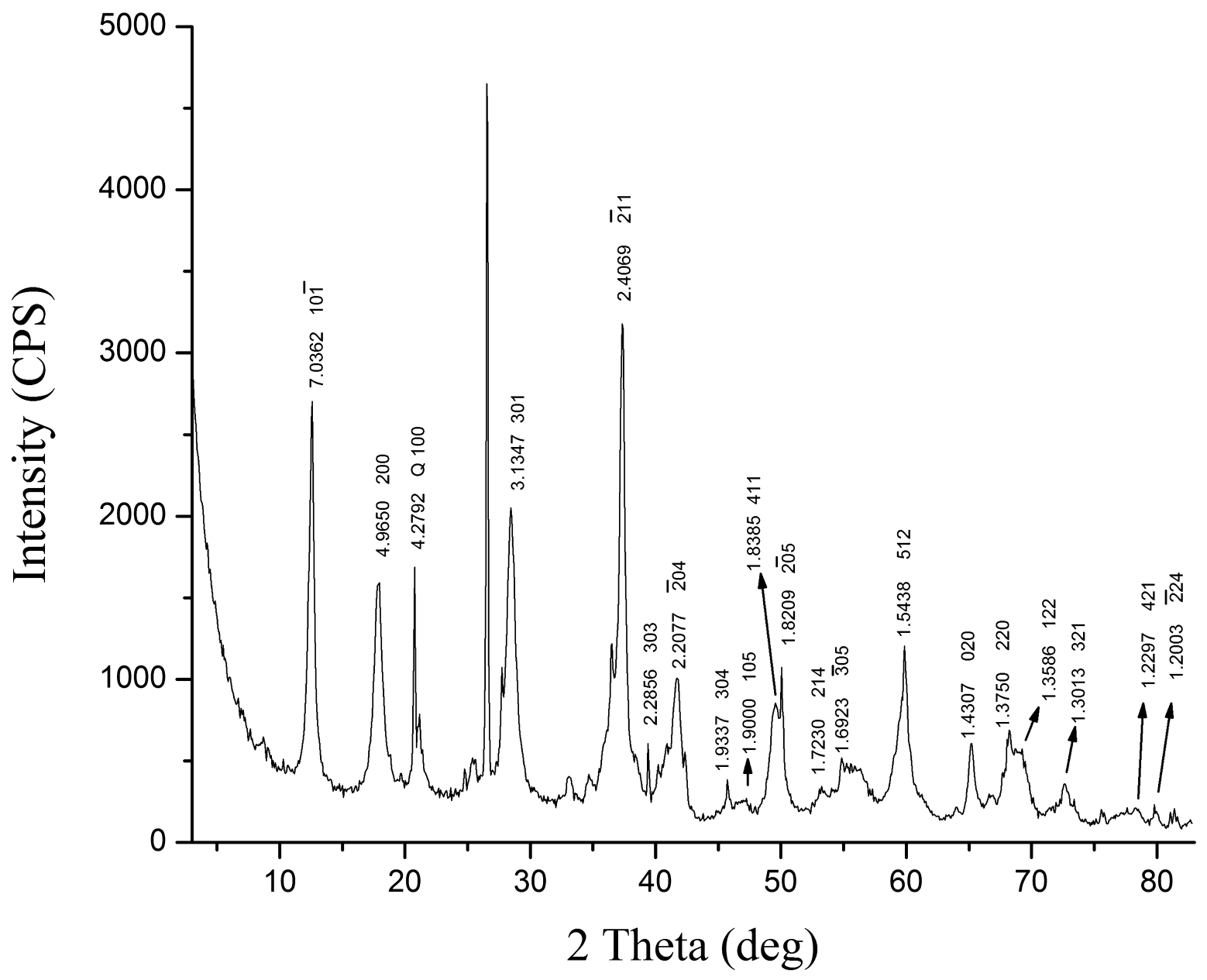

Figure 3. XRD patterns of XTM cryptomelane.

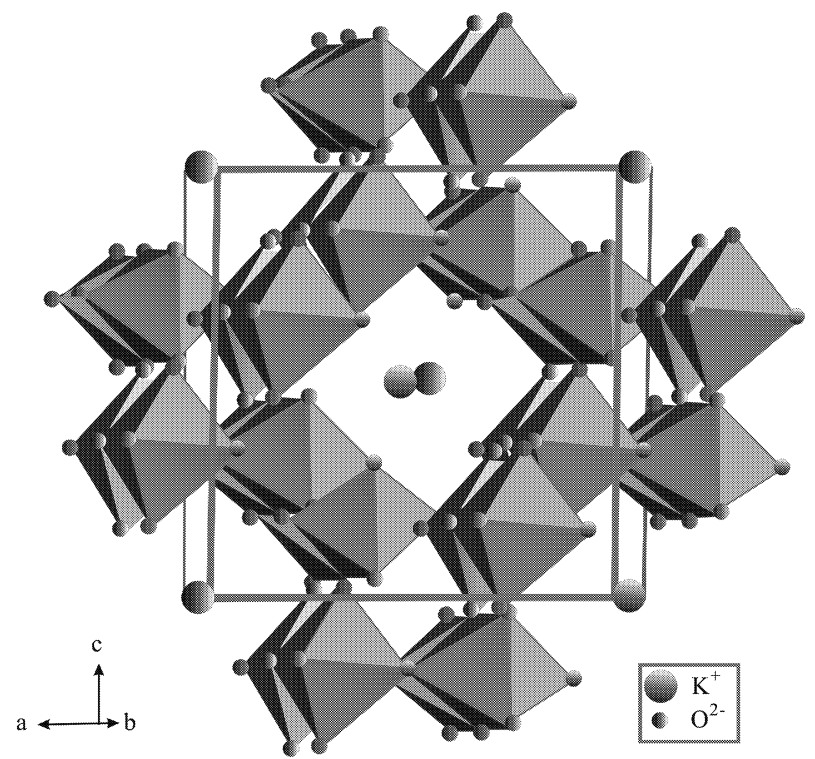

Figure 4. Projection of cryptomelane structure along b axis $\left(\mathrm{MnO}_{6}\right.$ octahedron).

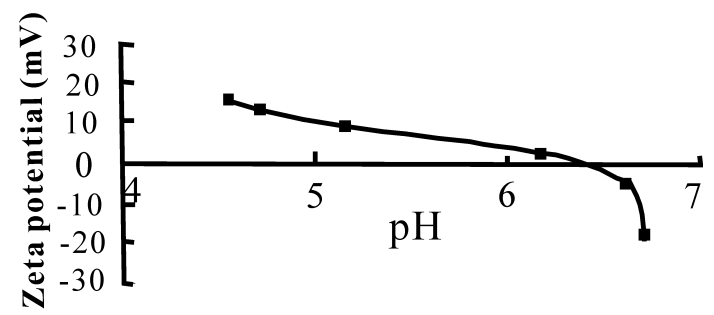

Figure 5. The zeta potential values of the natural cryptomelane surface.

report an equilibrium time of about one to two days for adsorption of $\mathrm{Co}^{2+}$ and $\mathrm{Zn}^{2+}$ by $\delta-\mathrm{MnO}_{2}$, and they point out that the slow reaction rate of $\mathrm{Co}^{2+}$ and $\mathrm{Zn}^{2+}$ might be due to their steady displacement of the manganese ions from structural positions. Our study showed (from Table 2 and Fig. 6) that the reaction rate was much faster within the first few hours than later. Rapid reaction in the first few hours might be the result of adsorption onto the sample surfaces in addition to within the tunnels, whereas the activity later might reflect slower uptake in tunnels, including the displacement of structural ions by $\mathrm{Cd}^{2+}$. 
Table 2. Data on reaction time and disposal capacities

\begin{tabular}{lcccccccc}
\hline Time $(\mathrm{h})$ & 1 & 2 & 3 & 6 & 12 & 24 & 48 & 72 \\
\hline Capacities (mg/g) & 1.11 & 1.226 & 1.425 & 1.451 & 1.558 & 1.392 & 1.700 & 1.753 \\
Percentage (\%) & 44.3 & 48.64 & 56.60 & 58.04 & 61.92 & 55.78 & 68.00 & 70.12 \\
\hline
\end{tabular}

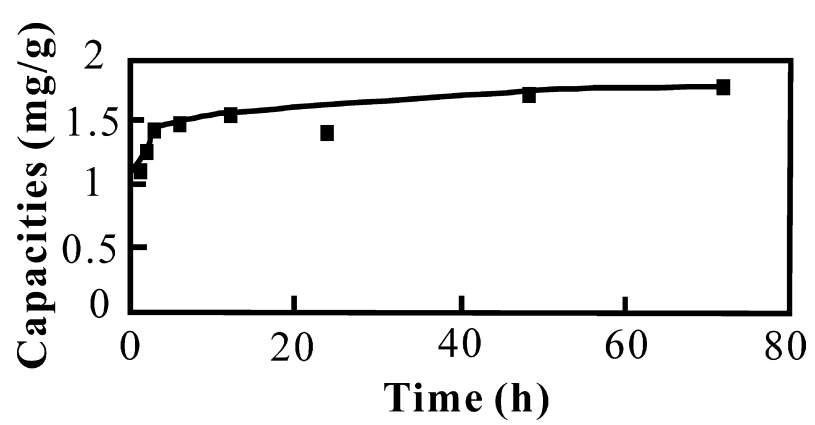

Figure 6. The relation of reaction time and disposal capacity.

The results of the leaching and holding experiments are shown in Table 3. In the blank experiment, only about $0.0948 \mathrm{mg} / \mathrm{g} \mathrm{Mn}^{2+}$ and $0.7448 \mathrm{mg} / \mathrm{g} \mathrm{K}^{+}$was leached from the cryptomelane. The concentrations of $\mathrm{Mn}^{2+}$ and $\mathrm{K}^{+}$ clearly increased after the adsorption of $\mathrm{Cd}^{2+}$. When the capacity of $\mathrm{Cd}^{2+}$ adsorption by cryptomelane was 2.255 $\mathrm{mg} / \mathrm{g}$, the leaching of $\mathrm{Mn}^{2+}$ and $\mathrm{K}^{+}$was $4.455 \mathrm{mg} / \mathrm{g}$ and $2.313 \mathrm{mg} / \mathrm{g}$, respectively. After ultrasonic cleaning and leaching, the cadmium held on cryptomelane was 1.800 $\mathrm{mg} / \mathrm{g}$ or $79.82 \%$ of the disposal capacity. From the above, we consider that leaching of $\mathrm{Mn}^{2+}$ and $\mathrm{K}^{+}$from cryptomelane is related to the adsorption of $\mathrm{Cd}^{2+}$. It is possible to conclude therefore, that $\mathrm{Cd}^{2+}$ is adsorbed on the cryptomelane surface and at the same time $\mathrm{Cd}^{2+}$ exchanges with $\mathrm{Mn}^{2+} / \mathrm{Mn}^{3+}$ and $\mathrm{K}^{+}$within inner structures. However, the uptake of $\mathrm{Cd}^{2+}$ and leaching of $\mathrm{Mn}^{2+}$ and $\mathrm{K}^{+}$show that the exchange of $\mathrm{Cd}^{2+}$ with $\mathrm{Mn}^{2+} / \mathrm{Mn}^{3+}$ and $\mathrm{K}^{+}$is on a small scale.

\section{Effect of pH and electrolytes on adsorption of $\mathrm{Cd}^{2+}$}

Experiments with several electrolytes were carried out to examine the effects of different cations on the disposal capacity of $\mathrm{Cd}^{2+}$. The capacities of $\mathrm{Cd}^{2+}$ adsorption versus $\mathrm{pH}$ values are shown in Figure 7.

The adsorption curves indicate that the disposal capacities of $\mathrm{Cd}^{2+}$ with all electrolytes improved with increasing $\mathrm{pH}$ as a whole, and reached maximum when the solution was alkaline, then dropped at higher $\mathrm{pH}$ values. The increasing disposal capacity with high $\mathrm{pH}$ may be related to the electrical property and amount of charge on the mineral surfaces. When $\mathrm{pH}<6.3$, below the zero point of charge $\left(\mathrm{pH}_{\mathrm{zpc}}\right)$ for cryptomelane, there are likely net positive surface charges (Randall et al., 1998) giving an electrostatic repulsion to $\mathrm{Cd}^{2+}$. As a result, the adsorption of the heavy metal ion is retarded. As $\mathrm{pH}$ values increase, the density of positive charges on the mineral surface becomes reduced, the electrostatic repulsion is decreased, and consequently the adsorption of $\mathrm{Cd}^{2+}$ is enhanced. As $\mathrm{pH}$ values are usually higher than $\mathrm{pH}_{\mathrm{zpc}}$, cation adsorption is favored (Gadde and Laitinen, 1974). Electrostatic attraction may exist with $\mathrm{pH}>6.3$, whereas $\mathrm{Cd}^{2+}$ adsorption is reduced at $\mathrm{pH}>11.5$, which may be due to the hydrolization of the metal ions with the solution becoming alkaline such that the $\mathrm{Cd}^{2+}$ are likely to combine with a hydroxyl ion. The processes can be formulated as follows (Anderson and Rubin, 1981):

$$
\begin{aligned}
& \mathrm{Cd}^{2+}+\mathrm{OH}^{-}=\mathrm{Cd}^{-}(\mathrm{OH})^{+} \\
& \mathrm{Cd}^{2+}+2 \mathrm{OH}^{-}=\mathrm{Cd}-(\mathrm{OH})_{2}^{0} \\
& \mathrm{Cd}^{2+}+3 \mathrm{OH}^{-}=\mathrm{Cd}^{-}(\mathrm{OH})_{3}^{-} \\
& \mathrm{Cd}^{2+}+4 \mathrm{OH}^{-}=\mathrm{Cd}-(\mathrm{OH})_{4}^{2-} .
\end{aligned}
$$

In our experiments, the increase of $\mathrm{pH}$ values after reaction (Table 4) might be due to the contribution of $\mathrm{OH}^{-}$ combined with $\mathrm{Cd}^{2+}$. The hydrolization decreased with the increased concentration of $\mathrm{Cd}^{2+}$ and may reduce the electrostatic attraction such that the adsorption ability becomes weak.

The experimental results indicate that with appropriate $\mathrm{pH}$ values the chlorides have a greater influence upon

Table 3. Data of metal ions in samples during leaching and retention

\begin{tabular}{cccccc}
\hline & Water $(\mathrm{mg} / \mathrm{L})$ & Blank $(\mathrm{mg} / \mathrm{g})$ & Filtrate $(\mathrm{mg} / \mathrm{g})$ & Residue $1(\mathrm{mg} / \mathrm{g})$ & Residue 2 $(\mathrm{mg} / \mathrm{g})$ \\
\hline $\mathrm{Cd}^{2+}$ & & & 178.9 & 2.255 & 1.800 \\
$\mathrm{Mn}^{2+}$ & 0.0027 & 0.0948 & 4.455 & & \\
$\mathrm{~K}^{+}$ & 0.0187 & 0.7448 & 2.313 & & \\
\hline
\end{tabular}

Water, $\mathrm{Mn}^{2+}$ and $\mathrm{K}^{+}$in the distilled water used; Blank, leaching $\mathrm{Mn}^{2+}$ and $\mathrm{K}^{+}$from cryptomelane in water; Residue 1 , $\mathrm{Cd}^{2+}$ in uncleaned residue; Residue $2, \mathrm{Cd}^{2+}$ in cleaned residue. 


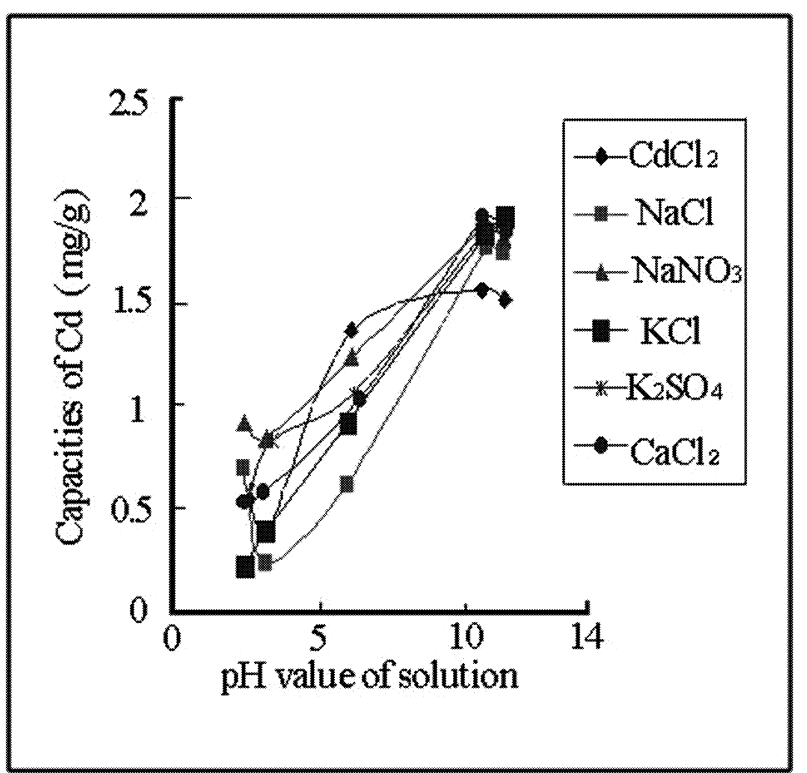

Figure 7. Effect of different $\mathrm{pH}$ values and electrolytes on $\mathrm{Cd}^{2+}$ adsorption. All the solutions had a $\mathrm{Cd}^{2+}$ concentration of $2 \mathrm{mg} / \mathrm{L}$; $\mathrm{CdCl}_{2}$ indicated for the nonelectrolyte solution.

the adsorption of $\mathrm{Cd}^{2+}$ than other electrolytes. It is obvious that the presence of the chlorine ion $\mathrm{Cl}^{-}$reduces the adsorption of the metal. The adsorption capacity for the metal ion $\mathrm{Cd}^{2+}$ in solution of $\mathrm{KCl}, \mathrm{NaCl}$, and $\mathrm{CaCl}_{2}$ is lower than that with $\mathrm{K}_{2} \mathrm{SO}_{4}$ and $\mathrm{NaNO}_{3}$. Generally, the mineral surface has a specific adsorption for anions, which may cause a static adsorption and increase the disposal capacity. However, the surface-specific adsorption of $\mathrm{NO}_{3}^{-}, \mathrm{SO}_{4}^{2-}$, and $\mathrm{Cl}^{-}$on minerals is so faint that it can be negligible. The anions may mainly influence the adsorption of metal ions by their state of coexistence with the metals rather than by specific adsorption. When the $\mathrm{Cl}^{-}$ ion in solution is at a certain concentration, it is prone to linking with $\mathrm{Cd}^{2+}$ to form complex ions such as $\mathrm{CdCl}^{+}$, $\mathrm{CdCl}_{2}, \mathrm{CdCl}_{3}^{-}$, and $\mathrm{CdCl}_{4}^{2-}$ (Anderson and Rubin, 1981), which may decrease the concentration of $\mathrm{Cd}^{2+}$ and subsequently reduce the adsorption of $\mathrm{Cd}^{2+}$ on minerals.

It is obvious that the adsorption of $\mathrm{Cd}^{2+}$ in nonelectrolyte solution in contrast to electrolytes increases dramatically at $\mathrm{pH} 3-6$. This may be due to the competition of cations for adsorption sites whereas the electrolyte can delay the adsorption of $\mathrm{Cd}^{2+}$. In spite of the common $\mathrm{Cl}^{-}$ anion, adsorption in $\mathrm{KCl}, \mathrm{NaCl}$, and $\mathrm{CaCl}_{2}$ solutions is not the same, which may be due to the different adsorption competition of $\mathrm{Na}, \mathrm{K}$, and $\mathrm{Ca}$ with the heavy metal ions.

Attention should be paid to the adsorption of cadmium in the $\mathrm{pH}<3$ area, which is exceptional to the whole tendency (Fig. 7). The curves, especially of the nonelectrolyte, indicate a dramatic decrease of adsorption at low $\mathrm{pH}$ and reach a minimum when close to $\mathrm{pH} 3$. Randall et al. (1998) studied the adsorption of aqueous cadmium on synthetic cryptomelane by EXAFS and found that two-thirds of the available $\mathrm{Cd}^{2+}$ were adsorbed from solution with $\mathrm{pH}$ as low as 2.0. They point out that the majority of adsorbed $\mathrm{Cd}^{2+}$ ions were located inside the tunnels and exchanged with $\mathrm{H}^{+}$rather than $\mathrm{K}^{+}$.

In our experiment, the adsorption of $\mathrm{Cd}^{2+}$ took place with cation exchange in the structure when $\mathrm{pH}$ was below 3 . Since the vacancies among neighboring potassium ions are necessary to minimize electrostatic repulsion in the structure (Loganathan and Burau, 1973), $\mathrm{H}^{+}$occupation in the tunnel sites is expected. Enhanced acidity will favor $\mathrm{H}^{+}$in the structure and the exchange with $\mathrm{Cd}^{2+}$. This argument may be validated by the decrease of $\mathrm{pH}$ values after reaction when $\mathrm{pH}<3$ (Table 4).

Table 4. Change of $\mathrm{pH}$ before and after reaction using different electrolytes

\begin{tabular}{cccccccc}
\hline & $\mathrm{NaCl}$ & \multicolumn{2}{c}{$\mathrm{NaNO}_{3}$} & \multicolumn{3}{c}{$\mathrm{CaCl}_{2}$} & \multicolumn{2}{c}{ Non-electrolyte } \\
$\mathrm{pH}$ & Post-pH & $\mathrm{pH}$ & Post-pH & $\mathrm{pH}$ & Post-pH & $\mathrm{pH}$ & Post-pH \\
\hline 2.66 & 2.52 & 2.43 & 2.16 & 2.36 & 2.37 & 2.87 & 2.51 \\
3.17 & 4.02 & 3.09 & 3.84 & 3.04 & 3.96 & 3.45 & 4.04 \\
5.67 & 6.86 & 5.9 & 6.64 & 6.19 & 6.4 & 5.88 & 6.46 \\
10.66 & 10.17 & 10.79 & 10.16 & 10.44 & 9.86 & 10.85 & 10.31 \\
11.46 & 11.29 & 11.16 & 11.25 & 11.08 & 11.22 & 11.33 & 11.41 \\
\hline
\end{tabular}

$\mathrm{pH}, \mathrm{pH}$ before reaction; Post-pH, $\mathrm{pH}$ after reaction.

Table 5. Data on the adsorption isotherm

\begin{tabular}{cccccccc}
\hline Initial (mg/L) & 1 & 2 & 5 & 10 & 20 & 50 & 100 \\
\hline Equilibrium (mg/L) & 0.020 & 0.186 & 1.524 & 6.429 & 11.000 & 39.772 & 89.371 \\
Capacity (mg/g) & 0.490 & 0.907 & 1.738 & 1.786 & 4.500 & 5.114 & 5.315 \\
Percentage (\%) & 98.00 & 90.70 & 69.52 & 35.72 & 45.00 & 20.45 & 10.63 \\
\hline
\end{tabular}




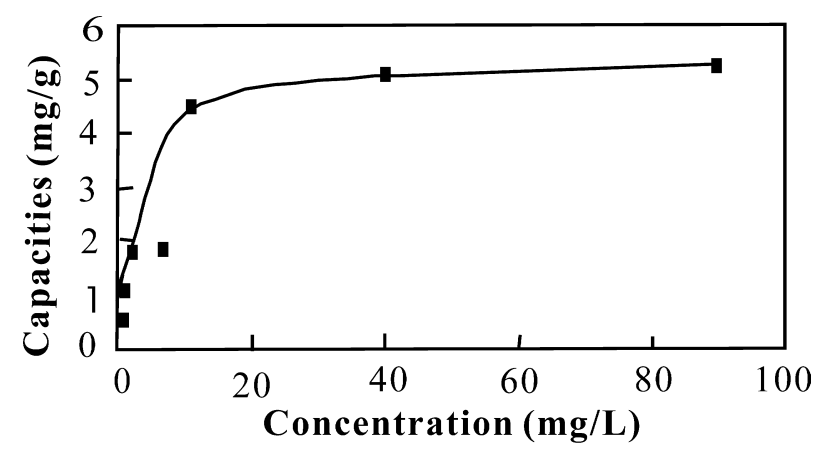

Figure 8. Adsorption isotherm of $\mathrm{Cd}^{2+}$.

\section{Adsorption isotherms}

Isotherms for $\mathrm{Cd}^{2+}$ adsorption by cryptomelane in solution at about neutral $\mathrm{pH}$ are shown in Table 5 and Figure 8. The isotherm curve shows that the equilibrium disposal capacity increased with the equilibrium concentration, which corresponds to a higher initial concentration. Although the capacity increased with the increase in initial concentration of $\mathrm{Cd}^{2+}$, the disposal ratios reduced at the same time.

The Langmuir isotherm has usually been considered as an effective model for the adsorption of heavy metals on hydrous manganese oxides in solution (Morgan and Stumm, 1964; Posselt et al., 1968; Loganathan and Burau, 1973). In our study, this isotherm was used to express the adsorption of cadmium ions by cryptomelane. The Langmuir expression was written in the linear form:

$$
c /(x / m)=1 / a b+c / a
$$

where $c=$ the equilibrium concentration of the solution $(\mathrm{mg} / \mathrm{L}), x / m=$ the disposal capacity $(\mathrm{mg} / \mathrm{g}), b=\mathrm{a}$ constant relating to the adsorbed energy, $a=$ the maximum disposal capacity $(\mathrm{mg} / \mathrm{g})$.

Generally, when the adsorption conforms to the Langmuir expression, a plot of $c /(x / m)$ versus $c$ will give a straight line with a slope of $1 / a$ and an intercept of $1 / a b$. In the present study, the adsorption of $\mathrm{Cd}^{2+}$ represented by Langmuir expression is shown in Figure 9, which yields a regress equation $y=0.1806 x+0.7103$ with a linear correlation coefficient of 0.9825 . From the regress equation, the theoretic maximum of the disposal capacity was determined following the Langmuir isotherm theory, such that when the initial concentration of $\mathrm{Cd}^{2+}$ is below $200 \mathrm{mg} / \mathrm{L}$, the maximum capacity of $\mathrm{Cd}^{2+}$ is $5.54 \mathrm{mg} / \mathrm{g}$.

\section{DISCUSSION}

The XRD pattern displays peaks that have the character of a high background, broadening, and asymmetry, which

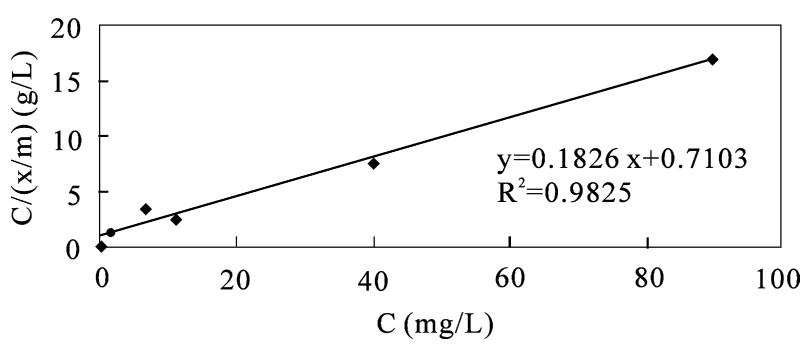

Figure 9. Langmuir plot for adsorption of $\mathrm{Cd}^{2+}$.

indicates a low degree of crystallinity. This result is in good agreement with the AFM and TEM images, which show that most crystals of cryptomelane have low idiomorphism and rounded hull, and have an acicular form with a diameter from $20 \mathrm{~nm}$ to $120 \mathrm{~nm}$. TEM images show that the crystal lattice is cryptomelane. Based on 20 observed peaks, the cell parameters were refined with the PIRUM program and given as $a_{0}=0.9974 \pm 0.0007 \mathrm{~nm}$, $b_{0}=0.2863 \pm 0.0001 \mathrm{~nm}, c_{0}=0.9693 \pm 0.0007 \mathrm{~nm}$, and $\beta=91.47^{\circ} \pm 0.01^{\circ}$. From the crystal structure model, there are large pseudotetragonal tunnels in natural cryptomelane formed by $\left[\mathrm{MnO}_{6}\right]$ octahedral double chains with an aperture of $0.462 \mathrm{~nm} \times 0.466 \mathrm{~nm}$.

The adsorption experiments displayed that the natural cryptomelane was able to adsorb the heavy cadmium metal ions on a large scale. More than $70 \%$ of $\mathrm{Cd}^{2+}$ can be adsorbed by cryptomelane in one or two days. In addition to the exchange with $\mathrm{H}^{+}$, the results of leaching and holding experiments showed that the adsorption of $\mathrm{Cd}^{2+}$ possibly involves exchange with $\mathrm{Mn}$ and $\mathrm{K}$ ions in the structure of cryptomelane at neutral $\mathrm{pH}$. After ultrasonic cleaning and leaching, the cadmium held on cryptomelane was $1.800 \mathrm{mg} / \mathrm{g}$ or $79.82 \%$ of the disposal capacity. This means that XTM cryptomelane has a great ability to adsorb and retain $\mathrm{Cd}^{2+}$. With different electrolytes, the disposal capacities of $\mathrm{Cd}^{2+}$ increased along with $\mathrm{pH}$ values generally. However, $\mathrm{Cd}^{2+}$ adsorption decreased with an increase of $\mathrm{pH}<3$, and $\mathrm{pH}$ decrease may be due to the exchange with $\mathrm{H}^{+}$after the reaction. The isotherms for the adsorption of $\mathrm{Cd}^{2+}$ on cryptomelane in about neutral $\mathrm{pH}$ solutions can be satisfactorily represented by the Langmuir expression. The theoretic maximum disposal capacity for $\mathrm{Cd}^{2+}$ as determined by this isotherm is 5.54 $\mathrm{mg} / \mathrm{g}$.

\section{ACKNOWLEDGMENT}

This work was generously supported by the National Key Program for Basic Research of China (No. 2001CCA 02400) and by the National Natural Science Foundation of China (Grant No. 49972017). 


\section{REFERENCES}

Acosta, C.A., Viola, M.C. and Pedregosa, J.C. (1991) Infrared spectroscopic and $\mathrm{X}$-ray diffraction characterization of calcium, M(III) and tungsten oxides. Journal of Materials Science Letters, 10, 251-252.

Anderson, M.A. and Rubin, A.J. (1981) Adsorption of inorganics at solid-liquid interfaces. Ann Arbor Science Publishers, New York, USA, 1-357.

DeGuzman, R.N., Shen, Y.F., Neth, E.J., Suib, S.L., O’Young, C.L., Levine, S. and Newsam, J.M. (1994) Synthesis and characterization of octahedral molecular sieves (OMS-2) having the hollandite structure. Chemistry of Materials, 6, 815-821.

Elnaggar, I.M., Elabsy, M.A., Abdelhamid, M.M. and Aly, H.F. (1993) Sorption behavior of uranium and thorium on crytomelane-type hydrous manganese dioxide from aqueous solution. Solvent Extraction \& Ion Exchange, 11, 521-540.

Feng, Q., Kanoh, H., Miyai, Y. and Ooi, K. (1995) Alkali metal ions insertion/extraction reactions with hollandite-type manganese oide in the aqueous phase. Chemistry of Materials, 7, 148-153.

Gadde, R.R. and Laitinen, H.A. (1974) Studies of heavy metal adsorption by hydrous iron and manganese oxides. Analytical Chemistry, 46, 2022-2026.

Gao, X., Lu, A.H., Qin, S., Zheng, D.S., Zheng, X.S. and Zheng, Z. (2001) Study of crystal structure and the exhibition of its environmental properties for natural cryptomelane. ACTA PETROLOGICA ET MINERALOGICA, 20, 477-484 (in Chinese).

Healey, T.W., Herring, A.P. and Fuersteau, D.W. (1966) The effect of crystal structure on the surface properties of a series of manganese dioxides. Journal of Colloid and Interface Science, 21, 435-444.

Li, G.Y., Lu, A.H. and Rao, Z. (2003) Mechanism of oxidation and degradation of phenol in water by natural cryptomelane. ACTA PETROLOGICA ET MINERALOGICA, 22 (4), 365368 (in Chinese).

Loganathan, P. and Burau, R.G. (1973) Sorption of heavy metal ions by a hydrous manganese oxide. Geochimica et Cosmochimica Acta, 37, 1277-1293.

Lu, A.H., Gao, X., Qin, S. and Wang, C.Q. (2003) Cryptomelane $\left(\mathrm{K}_{\mathrm{x}} \mathrm{Mn}_{8-\mathrm{x}} \mathrm{O}_{16}\right)$ : Natural active octahedral molecular sieve (OMS-2). Chinese Science Bulletin, 48, 920-923.

Luo, J., Zhang, Q.H., Huang, A.M., Huang, A. and Suib, S.L. (2000) Total oxidation of volatile organic compounds with hydrophobic cryptomelane-type octahedral molecular sieves. Microporous and Mesoporous Materials, 35-36, 209-217.

McKenzie, R.M. (1970) The reaction of cobalt with manganese dioxide minerals. Australian Journal of Soil Research, 8, 97106.

McKenzie, R.M. (1980) The absorption of lead and other heavy metals on dioxide of manganese and iron. Australian Journal of Soil Research, 18, 61-74.

McKenzie, R.M. (1981) The surface charge of manganese dioxides. Australian Journal of Soil Research, 19, 41-50.

Morgan, J.J. and Stumm, W. (1964) Colloid chemical properties of manganese dioxide. Journal of Colloid and Interface Sci- ence, 19, 347-359.

Mukherjee, B. (1959) X-ray study of psilomelane and cryptomelane. Mineralogical Magazine, 32, 166-171.

Murray, D.J., Healy, T.W. and Fuerstenau, D.W. (1968) The adsorption of aqueous metal on colloidal hydrous manganese oxide. Adv. Chem., 79, 74-81.

Murray, J.W. (1975a) The interaction of metal ions at the manganese dioxide-solution interface. Geochimica et Cosmochimica Acta, 39, 505-519.

Murray, J.W. (1975b) The interaction of cobalt with hydrous manganese dioxide. Geochimica et Cosmochimica Acta, 39, 635647.

Murray, J.W. and Dillard, J.G. (1979) The oxidation of cobalt (II) adsorbed on manganese dioxide. Geochimica et Cosmochimica Acta, 43, 781-78.

Posselt, H.S., Anderson, F.J. and Weber, W.J. (1968) Cation sorption on colloidal hydrous manganese oxide. Environment Science and Technology, 2, 1087-1093.

Post, J.E. (1999) Manganese oxide minerals: Crystal structures and economic and environmental significance. Procedings of National Academy of Science, USA, 96, 3447-3454.

Ramsdell, L.S. (1932) An X-ray study of psilomelane and wad. American Mineralogist, 17, 143-149.

Randall, S.R., Sherman, D.M. and Ragnarsdottir, K.V. (1998) An extended $\mathrm{X}$-ray absorption fine structure spectroscopy investigation of cadmium sorption on cryptomelane $\left(\mathrm{KMn}_{8} \mathrm{O}_{16}\right)$. Chemical Geology, 151, 95-106.

Richmond, W.E. and Fleischer, M. (1942) Cryptomelane, a new name for the commonest of the "psilomelane" minerals. American Mineralogist, 27, 607-613.

Shen, Y.F., Zerger, R.P., DeGuzman, R.N., Suib, S.L., McCurdy, L., Potter, D.I. and O'Young, C.L. (1993) Manganese oxide octahedral molecular sieves: preparation, characterization, and applications. Science, 260, 511-515.

Tsuji, M. and Komarneni, S. (1993a) Powder X-ray differaction study of a cryptomelane-tyoe manganic acid and its alkali cation exchanged forms. Journal of Materials Research, 8, 3145-3150.

Tsuji, M. and Komarneni, S. (1993b) Selective exchange of divalent transition metal ions in cryptmeae-type manganic acid with tunnel sttucture. Journal of Materials Research, 8, 611616.

Vicat, J., Fanchon, E., Strobel, P. and Qui, D.T. (1986) The structure of $\mathrm{K}_{1.33} \mathrm{Mn}_{8} \mathrm{O}_{16}$ and cation odering in hollandite-type structure. Acta Crystallography, B42, 162-167.

Wang, P., Pan, Z.L. and Weng, L.B. (1982) Systematic Mineralogy, First volume (in Chinese). Geological Press, Beijing, 546-567.

Yin, Y.G, Xu, W.Q., DeGuzman, R. and Suib, S.L. (1994) Studies of stability and reactivity cryptomelane-like manganese oxide octahedral molecular sieves. Inorganic Chemistry, 33, 4384-4389.

Manuscript received April 12, 2006

Manuscript accepted December 15, 2006

Published online April 3, 2007

Manuscript handled by Motoharu Kawano 